\title{
Pembuatan Akta Jaminan Fidusia Berdasarkan Alat Bukti Kuitansi Jual Beli Kendaraan Bermotor
}

\author{
Niedia Happy ${ }^{1}$ \\ ${ }^{1}$ Program Studi Magister (S2) Kenotariatan Fakultas Hukum Universitas Udayana, Bali- \\ Indonesia, E-mail : E-mail: happynidia@yahoo.com
}

\begin{tabular}{l}
\hline Info Artikel \\
\hline Keywords : \\
Fiduciary Deed, Selling \\
Receipt, Motor Vehicle \\
\\
DOI : \\
10.24843/AC.2018.v03.i03.p1 \\
Kata kunci: \\
Akta Fidusia, Kuitansi, \\
Kendaraan bermotor \\
E-mail: happynidia@yahoo.com \\
\end{tabular}

\begin{abstract}
The obligation of fiduciary guarantee is the imposition to a movable object both tangible and intangible and immovable objects, especially buildings, that cannot be burdened with mortgages. The imposition of objects with fiduciary collateral is made in the form of a notary deed which is a fiduciary guarantee deed. An object that is guaranteed by fiduciary is used as collateral for debt in which the ownership of the object is conveyed to the creditor whereas the physical property is still controlled by the debtor. The fiduciary imposition of motor vehicles will then be made in the form of a fiduciary deed before the notary in the presence of debtors, creditors and witnesses. The problems of this study are the validity of receipt as proof of ownership of motor vehicles in the making of fiduciary deeds and sanctions for notaries if there are problems with the fiduciary deeds that are made regarding receipt used as evidence. The purpose of this journal research is to prove the validity of receipts as evidence in making a fiduciary guarantee deed. This study is an empirical study with primary data sources and secondary data which is concluded through descriptive analysis techniques. The results of the study show that a notary who makes a fiduciary deed whose imposition is in the form of a motor vehicle must pay attention to the name of the debtor who signs the fiduciary deed; ensuring that it is in accordance with the name stated in the proof of ownership of the motor vehicle (BPKP). In the case that a debtor wanting to pledge a motor vehicle having only a receipt as proof of ownership of the motor vehicle, the notary should suggest the debtor to process the title transfer first so that later it does not cause problems with the fiduciary deed that has been made.
\end{abstract}

\begin{tabular}{l}
\hline Abstrak \\
\hline Pembebanan jaminan fidusia adalah pembebanan terhadap suatu \\
benda bergerak baik yang berwujud maupun yang tidak \\
berwujud dan benda tidak bergerak khususnya bangunan yang \\
tidak dapat dibebani hak tanggungan. Pembebanan benda dengan \\
jaminan fidusia dibuat dalam bentuk akta notaris yang \\
merupakan akta jaminan fidusia. Suatu benda yang dijaminkan \\
fidusia digunakan sebagai jaminan utang dimana kepemilikan \\
hak atas benda tersebut diahlikan kepada pihak kreditor \\
sedangkan fisik benda tersebut masih dikuasai pihak debitornya. \\
Pembebanan fidusia terhadap kendaraan bermotor selanjutnya \\
akan dibuatkan dalam bentuk akta jaminan fidusia dihadapan
\end{tabular}


pihak notaris dengan dihadiri pihak debitor dan pihak kreditor serta para saksi. Permasalahan dalam penelitian ini yaitu mengenai keabsahan kuitansi sebagai tanda bukti kepemilikan kendaraan bermotor didalam pembuatan akta fidusia dan sanksi bagi notaris jika terjadi permasalahan pada akta fidusia yang dibuatnya terkait kuitansi yang digunakan sebagai alat bukti. Tujuan penelitian jurnal ini adalah untuk membuktikan keabsahan kuitansi sebagai alat bukti dalam pembuatan suatu akta jaminan fidusia. Penelitian ini merupakan penelitian empiris dengan sumber data primer dan data sekunder yang disimpulkan melalui teknik analisis deskriptif. Hasil penelitian menunjukan bahwa seorang Notaris yang membuat akta fidusia yang pembebanannya berupa kendaraan bermotor harus memperhatikan nama pihak debitor yang menandatangi akta fidusia harus sesuai dengan nama yang tertera dalam bukti kepemilikan kendaraan bermotor (BPKP) tersebut. Pihak debitor yang ingin menjaminkan kendaraan bermotor sedangkan hanya memiliki kuitansi sebagai alat bukti kepemilikan kendaraan bermotor tersebut sebaiknya pihak notaris menyarankan untuk melakukan proses balik nama terlebih dahulu agar nantinya tidak menimbulkan permasalahan terhadap akta fidusia yang sudah dibuat.

\section{Pendahuluan}

Beragamnya jenis kebutuhan masyarakat saat ini menuntut masyarakat untuk dapat memenuhi kebutuhannya. Salah satu upaya yang dilakukan kebanyakan masyarakat adalah dengan mengajukan permohonan kredit untuk dapat memenuhi kebutuhannya. Pengajuan kredit pada umumnya diikuti dengan penyerahan jaminan kepada pihak penerima jaminan atau disebut dengan pihak kreditor. Dengan adanya penyerahan jaminan tersebut merupakan suatu upaya perlindungan bagi pihak kreditor ketika pihak pemberi jaminan atau disebut dengan pihak debitor cidera janji atau tidak mampu membayar utang yang dimilikinya. Salah satu pembebanan jaminan yang sering digunakan adalah pembebanan jaminan kebendaan yang salah satunya adalah jaminan fidusia. Barang bergerak merupakan objek dari jaminan fidusia . Dalam jaminan fidusia adanya pemindahan hak kepemilikan dari pemberi fidusia ke penerima fidusia atas dasar kepercayaan dengan satu syarat bahwa objeknya masih ditangan pihak pemberi fidusia. ${ }^{1}$ Pihak pemberi fidusia atau disebut pihak debitor akan mengalihkan hak kepemilikannya atas suatu benda bergerak untuk pelunasan utang dengan kesepakat bahwa benda tersebut secara fisik masih dikuasai oleh pihak debitor sedangkan pihak kreditor hanya memagang alas haknya saja. ${ }^{2}$

Pengertian fidusia diatur dalam ketentuan pasal 1 angka 1 Undang - Undang nomor 42 tahun 1999 tentang jaminan fidusia menentukan fidusia adalah pengalihan suatu hak kepemilikan atas suatu benda atas dasar kepercayaan dengan ketentuan bahwa

\footnotetext{
${ }^{1}$ Nenden Dewi Anggraeni. (2012). Analisis Perlindungan Hukum Pemegang Jaminan Fidusia Studi Kasus Putusan Mahkamah Agung Nomor 1602/Pdt/2007 (Thesis, Program Magister kenotariatan Universitas Indonesia, h. 3

2 Rachmadi Usman. (2009). Hukum Jaminan Keperdataan. Jakarta: Sinar Grafika, h. 151
} 
terhadap benda yang hak kepemilikannya dialihkan tersebut tetap dalam penguasaan pemilik benda. Berdasarkan pengertian fidusia tersebut dapat diketahui unsur pokok dari fidusia adalah adanya pengalihan hak kepemilikan suatu benda, dilaksanakan berdasarkan kepercayaan dan yang mana benda yang dijaminkan tersebut masih dikuasai oleh pihak pemberi fidusia.

Pembebanan suatu benda dengan jaminan fidusia dibuatkan didalam bentu suatu akta autentik didalam bahasa Indonesia yang merupakan akta jaminan fidusia yang diatur dalam ketentuan pasal 5 ayat 1 Undang - Undang nomor 42 tahun 1999 tentang jaminan fidusia. Adanya ketentuan yang ada pada pasal 1870 Kitab Undang - Undang Hukum Perdata(untuk selanjutnya disebut KUHPerdata) yang menentukan suatu akta autentik akan memberikan suatu bukti yang sempurna mengenai apa yang dimuat didalam akta tersebut diantara para pihak serta para ahli warisnya ataupun orang yang akan mendapatkan haknya sebagai penggantinya. Dengan adanya ketentuan didalam pasal 1870 KUHPerdata tersebut mengakibatkan didalam undang - undang fidusia mewajibkan terhadap suatu benda yang dijamin dengan jaminan fidusia dibuatkan dalam bentuk akta autentik.

Bentuk akta autentik yang dibuat oleh notaris dipilih didalam pembuatan akta pembebanan jaminan fidusia adalah untuk memberikan perlindungan hukum kepada para pihak serta adanya peran notaris didalamnya juga dapat berperan sebagai penasihat hukum terhadap para pihak melalui nasihat yang disampaikan sehingga para pihak bisa sadar akan akibat hukum yang dapat muncul dari tindakan mereka yang melawan hukum. ${ }^{3}$ Selain itu dengan dibuatnya akta jaminan fidusia didalam bentuk akta autentik maka pihak notaris memiliki kewajiban untuk membacakan akta tersebut sebelum para pihak menandatangani akta tersebut. Benda yang menjadi objek dari jaminan fidusia merupakan benda bergerak yang tidak terdaftar sehingga hal tersebut juga mengakibatkan bentuk autentiklah yang pantas untuk dapat memberikan suatu jaminan hukum yang berkenaan dengan objek jaminan fidusia. ${ }^{4}$

Pengertian notaris diatur dalam ketentuan pasal 1 angka 1 Undang - Undang Nomor 2 tahun 2014 tentang perubahan atas undang - undang nomor 30 tahun 2004 tentang jabatan notaris (untuk selanjutnya disebut UUJN) menentukan notaris merupakan pejabat umum yang berwenang membuat akta autentik dan memiliki kewenangan lain yang dimaksudkan dalam undang - undang ini maupun undang - undang lainnya. Terhadap kewajiban pihak notaris diatur dalam ketentuan pasal 15 UUJN. Seorang notaris juga merupakan pejabat umum yang dapat memberikan suatu kepastian hukum kepada warga masyarakat untuk dapat menegakan hukum. Suatu akta autentik yang dibuat oleh notaris akan memiliki kekuatan pembuktian yang sempurna sehingga dapat sebagai upaya pencegahan serta sebagai penyelesaian sengketa ketika dikemudian hari adanya sengketa diantara para pihak yang dengan sengaja melakukan perbuatan yang merugikan pihak lain yang melanggar daripada ketentuan yang ada dalam akta tersebut. Dibuatnya akta jaminan fidusia dalam bentuk autentik maka sebagai upaya pencegahan ketika terjadinya sengketa dikemudian hari antara pihak pemberi jaminan fidusia dengan pihak penerima jaminan fidusia.

${ }^{3} \mathrm{Ibid}$, h. 190

${ }^{4}$ Fred B.G.Tumbuan. (2009). Mencermati Pokok-Pokok RUU Jaminan Fidusia. Newsletter Nomor 38 Tahun X. Jakarta : Yayasan pusat pengkaijian hukum. h. 17 
Dipilihnya lembaga jaminan fidusia sebagai lembaga jaminan untuk pembebanan benda bergerak seperti kendaraan bermotor karena dianggap lembaga jaminan fidusia ini sesuai dengan kebutuhan para masyarakat serta prosedur yang ditempuh tidak ruwet yang memakan biaya yang lebih terjangkau serta didalam proses penyelesaiannya memakan waktu cepat. ${ }^{5}$ Bentuk dari jaminan yang diinginkan oleh pihak pemberi jaminan adalah jaminan yang tidak merugikan kegiatan usaha milik pemberi fidusia sedangkan bagi pihak penerima jaminan yang diinginkan adalah jaminan yang memberikan kepastian hukum kepada pihak penerima jaminan serta pihak penerima jaminan dapat memperoleh piutangnya kembali tepat waktunya. Hal tersebut yang membuat dipilihnya lembaga jaminan fidusia karena walaupun bendanya dijadikan jaminan tapi masih bisa dikuasai oleh pihak pemberi jaminan fidusia yang mungkin masih dapat digunakan untuk menjalankan usahanya. Bagi pihak penerima jaminan yang memegang alas hak atau bukti kepemilikikan atas benda yang dijadikan jaminan merupakan pihak kreditor yang memiliki hak previlige atau kreditor yang diutamakan. ${ }^{6}$ Hak previlige diatur didalam ketentuan pasal 1134 KUHPerdata yang menentukan pengertian hak previlige adalah suatu hak yang diberikan oleh Undang - Undang terhadap pihak yang memiliki piutang sehingga pihak tersebut memiliki tingkatan lebih tinggi daripada pihak berpiutang lainnya yang didasarkan pada sifat piutangnya.

Pada prakteknya terhadap proses pembuatan akta fidusia maka terhadap pihak yang ingin membebankan benda bergerak yaitu kendaraan bermotor yang dimilikinya maka harus membuktikan kepemilikan Buku Kepemilikan kendaraan Bermotor (untuk selanjutnya disebut BPKB). Nama yang yang tertera didalam BPKB harus sama dengan nama pihak pemilik kendaraan bermotor yang akan menjaminkan kendaraannya tersebut yang tertera dalam Kartu Tanda Penduduk (untuk selanjutnya disebut KTP) yang dimilikinya. Pada prakteknya didalam pembuatan akta jaminan fidusia adanya para pihak yang datang ke hadapan notaris untuk meminta dibuatkannya akta jaminan fidusia tetapi hanya membawa bukti kuitansi sebagai bukti kepemilikan kendaraan bermotor tersebut. Hal tersebut dalam prakteknya ada notaris yang mau langsung membuatkan akta jaminan fidusia terkait dengan hanya alat bukti kuitansi sebagai tanda kepemilikan kendaraan tersebut dan ada pihak notaris yang menolak untuk membuatkan akta jaminan fidusia. Hal tersebut kembali pada notaris masing masing didalam mengemban tugasnya sebagai pejabat public yang sebaiknya tunduk pada ketentuan kode etik notaries dan UUJN. Berdasarkan pemaparan di atas, penting dilakukannya penelitian mengenai: Bagaimanakah keabsahan kuitansi sebagai tanda bukti kepemilikan kendaraan bermotor didalam pembuatan akta jaminan fidusia?, dan Apa sanksi bagi pihak notaris jika terjadi permasalahan terhadap akta jaminan fidusia yang dibuatnya terkait dengan alat bukti kuitansi?.

\section{Metode Penelitian}

Jenis penelitian yang digunakan dalam penelitian ini adalah penelitian hukum empiris. Penelitian hukum empiris merupakan suatu penelitian dengan cara meneliti

\footnotetext{
${ }^{5}$ Hayatdian, H. D. (2013). Kajian Hukum Surat Kuasa Dibawah Tangan Sebagai Dasar Pembuatan Akta Jaminan Fidusia. Jurnal Hukum Unsrat, 1(1), 120-135. h.5

${ }^{6}$ Winarno, J. (2013). Perlindungan Hukum bagi Kreditur pada Perjanjian Jaminan Fidusia. Jurnal Independent, 1(1). h. 1
} 
data sekunder mulai awal penelitian dilakukan dan dilanjutkan dengan meneliti data primer yang ada di lapangan yaitu responden dari pihak masyarakat secara langsung. ${ }^{7}$ Data primer diperoleh dari sumber pertama. Terhadap data sekunder diperoleh dari bahan - bahan kepustakaan, arsip- arsip maupun dokumen-dokumen yang terdiri dari bahan hukum primer yaitu kitab Undang - Undang Hukum Perdata (Burgerlijk Wetboek), Undang - Undang Nomor 2 Tahun 2014 tentang Perubahan atas Undang Undang Nomor 30 Tahun 2004 tentang Jabatan Notaris dan Undang - Undang Nomor Nomor 42 Tahun 1999 tentang Jaminan Fidusia dan bahan hukum sekunder yaitu karya ilmiah, hasil penelitian terdahulu dan hasil karya dari praktisi hukum dan sejenisnya. Data di dalam penelitian ini dikumpulkan dengan telaah kepustakaan terhadap bahan- bahan hukum dan melalui wawancara yang dilakukan secara langsung, dengan mengajukan beberapa macam pertanyaan kepada para informan yang memiliki kewenangan terkait dengan permasalahan yang akan dibahasa untuk memperoleh jawaban yang relevan. Setelah data - data terkumpul maka dianalisis secara analisis deskriptif yang didukung dengan metode kualitatif untuk memperoleh kesimpulan yang tepat. ${ }^{8}$

\section{Hasil dan Pembahasan}

\subsection{Keabsahan Kuitansi sebagai Tanda Bukti Kepemilikan Kendaraan Bermotor} Didalam Pembuatan Akta Jaminan Fidusia

Menurut ketentuan dalam Pasal 1866 KUHPerdata menentukan macam - macam jenis alat bukti yaitu :

a. Bukti tulisan atau bukti surat

b. Saksi - sanksi

c. Persangkaan- persangkaan

d. Pengakuan

e. Sumpah

Menurut ketentuan dalam pasal 1867 menentukan pembuktian dengan surat maupun tulisan dilakukan melalui tulisan autentik maupun tulisan dibawah tangan. Alat bukti surat maupun tulisan didalam KUHPerdata diatur didalam ketentuan pasal 1867 sampai 1894 KUHPerdata. Didalam Persoalan perdata dijelaskan bahwa alat bukti tulisan adalah alat bukti yang diutamakan dibandingkan alat bukti lainnya. Suatu tulisan dapat berbentuk suatu akta. Pada umumnya bentuk suatu akta dapat dibedakan menjadi dua antara lainnya akta autentik yang merupakan akta yang dibuat oleh pejabat yang berwenang dan akta dibawah tangan yang merupakan suatu akta yang hanya dibuat oleh para pihak tanpa adanya campur tangan dari pejabat yang berwenang. Akta dibawah tangan dibuat oleh para pihak atas dasar kesepakatan para pihak tanpa ada campur tangan pejabat yang berwenang. Contoh dari akta dibawah tangan yaitu surat perjanjian utang piutang serta kuitansi yang termasuk didalamnya. ${ }^{9}$

Kuitansi digolongkan sebagai alat bukti surat. Kuitansi merupakan suatu tanda terima maupun suatu pembebasan yang mana orang yang tercantum namanya didalam

\footnotetext{
${ }^{7}$ Soerjono Soekanto. (2012). Pengantar penelitian Hukum. Jakarta: UI Press. h .52

${ }^{8} \mathrm{Ibid}, \mathrm{h} .32$

9 Palit, R. C. (2015). Kekuatan Akta di Bawah Tangan Sebagai Alat Bukti di Pengadilan. Lex Privatum, 3(2). h. 2
} 
kuitansi tersebut menguasainya karena telah dianggap memenuhi pembayaraan sesuai dengan perintah pihak yang menandatanganinya. Pengertian kuitansi adalah merupakan suatu alat bukti atas penerimaan sejumlah uang yang mana ditandatangani oleh pihak penrima kemudian akan diserahkan kepada pihak yang telah membayar yang dapat digunakan sebagai alat bukti transaksi ${ }^{10}$. Kuitansi berfungsi sebagai surat atas tunjuk.

Kuitansi digolongkan sebagai alat bukti dibawah tangan yang memiliki suatu pembuktian yang hanya bersifat formil yang kekuatan pembuktiannya tidak sempurna seperti kekuatan pembuktian suatu surat maupun tulisan autentik yang memiliki pembuktian yang besifat formil dan materiil. Suatu kuitansi didalamnya tertera tanda tangan yang artinya mempunyai suatu kekuatan hukum jika tanda tangan tersebut diakui oleh para pihak. Umumnya didalam kuitansi terdapat suatu materai yang berfungsi untuk membubuhi isi kuitansi tersebut agar tidak melanggar hukum serta adanya suatu perjanjian yang maka akan berlaku sebagai undang - undang bagi mereka yang membuatnya.

Pembuatan suatu akta jaminan fidusia dibuat dalam bentuk akta notariil. Ketentuan mengenai pembebanan benda dengan jaminan fidusia dibuat dengan akta Notaris diatur didalam ketentuan pasal 5 ayat (1) Undang - Undang nomor 42 tahun 1999 tentang Jaminan fidusia. Bentuk notariil dari akta jaminan fidusia dipilih agar suatu tindakan yang membawa akibat hukum yang luas bagi para pihak dapat terlindungi dari tindakan kekeliruan, adanya peran notaris didalamnya juga bertindak sebagai penasihat hukum untuk para pihak dan dengan nasihat yang disampaikan pihak notaris diharapkan para pihak sadar akan akibat hukum yang bisa muncul dari tindakan yang mereka lakukan. ${ }^{11}$ Proses didalam pembuatan akta jaminan fidusia maka adanya kewajiban pihak notaris yang diatur dalam ketentuan 16 ayat (1) huruf untuk membacakan isi akta jaminan fidusia tersebut sebelum ditandatanganinya akta tersebut oleh para pihak yang bersangkutan, yang mana bisa berfungsi sebagai upaya perlindungan dari tindakan yang gegabah.

Terhadap jaminan fidusia harus didaftarkan hal tersebut diatur didalam ketentuan pasal 11 Undang - Undang nomor 42 tahun 1999 tentang jaminan fidusia. Adanya pendaftaran jaminan fidusia maka memenuhi asas publisitas yang merupakan suatu asas yang utama dari hukum jaminan kebendaan. Dibuatnya ketentuan tersebut agar benda yang dalam hal ini kendaraan bermotor yang dijadikan objek jaminan fidusia memang kepunyaan sendiri dari pihak yang membebankan jaminan fidusia tersebut. ${ }^{12}$

Keabsahan kuitansi sebagai tanda bukti kepemilikan kendaraan bermotor didalam pembuatan akta fidusia hanya sebagai suatu alat bukti surat dibawah tangan yang pembuktiannya hanya bersifat formil sehingga tidak memiliki kekuatan pembuktian yang sempurna hal tersebut karena didalam proses pembuatan surat dibawah tangan tersebut hanya disesuaikan dengan kehendak para pihak serta tidak adanya campur tangan dari pihak pejabat yang berwenang. Berbeda dengan bukti kepemilikan

\footnotetext{
${ }^{10}$ Imam Prayoga Suryohadibroto, Djoko Prakoso. (2010). Surat Berharga Alat Pembayaran dalam Masyarakat Moderen. Jakarta: PT Bina Aksara. h. 325

11 Rachmadi Usman. Op.cit, h. 192
} 
kendaraan bermotor berdasarkan BPKB yang merupakan suatu bukti kepemilkan kendaraan bermotor yang dibuat oleh pejabat yang berwenang sehingga termasuk sebagai alat bukti surat autentik yang memiliki pembuktian yang sempurna. Terhadap pihak yang ingin menjaminkan kendaraan bermtornya dengan pembebanan jaminan fidusia harus dapat menunjukan bukti autentik kepemilikan kendaraan bermotor tersebut agar tidak menimbulkan masalah dikemudian harinya.

Menurut Notaris I Ketut Mustika Udaya, SH selaku notaris dan PPAT di kabupaten tabanan menjelaskan pernah didatangi oleh klien yang ingin membuat akta jaminan fidusia namun klien tersebut hanya memiliki bukti kuitansi sebagai bukti tanda kepemilikan kendaraan bermotor. Menurut bapak I Ketut Mustika Udaya, SH menjelaskan menurut beliau bahwa kuitansi bukan merupakan suatu alat bukti sehingga beliau menolak untuk membuatakan akta jaminan fidusia tersebut. Menurut beliau didalam suatu akta jaminan fidusia tersebut nama pihak yang akan menandatangi akta jaminan fidusia selaku pihak pemberi jaminan fidusia harus sesuai dengan nama yang tertera didalam BPKB sebagai tanda bukti pemilik dari kendaraan bermotor tersebut. Dalam hal klien yang datang hanya membawa bukti kuitansi walapupun dengan adanya bukti kuitansi tersebut pihak klien menyatakan sebagai pemilik baru kendaraan bermotor tersebut tapi menurut bapak I Ketut Mustika Udaya,SH lebih baik melakukan upaya preventif karena jika dikemudian hari akta jaminan fidusia yang dibuatnya berdasarkan alat bukti kuitansi mengalami masalah maka hal tersebut akan mengikutsertakan beliau selaku pejabat yang membuat akta jaminan fidusia tersebut. Selain itu jika dibuatkannya akta jaminan fidusia maka ketika masuk dalam proses penandatangan akta jaminan fidusia nama pihak pemberi jaminan fidusia akan tidak sesuai dengan nama yang tertera didalam BPKB karena belum adanya proses balik nama.

Menurut Bapak I Ketut Mustika Udaya ,SH jika adanya klien yang demikian maka beliau akan menyarankan kepada klien tersebut untuk melakukan proses balik nama terlebih dahulu agar pada proses penadatanganan para pihak nama pihak pemberi jaminan fidusia akan sesuai dengan nama yang tertera didalam BPKPB. Permasalahan yang menyebabkan klien datang hanya membawa bukti kuitansi sebagai bukti pemilik kendaraan bermotor yang akan dibebankan jaminan fidusia dikarenakan menurut bapak I Ketut Mustika Udaya, SH karena adanya beberapa masyarakat yang enggan melakukan proses balik nama hal tersebut dikarenakan memakan biaya yang lumayan mahal serta proses balik nama juga memakan waktu.

\subsection{Sanksi Bagi Pihak Notaris Jika Terjadi Permasalahan Pada Akta Jaminan Fidusia Dibuatnya Terkait Kuitansi Yang Digunakan Sebagai Alat Bukti}

Profesi Notaris didalam membuat suatu akta merupakan suatu jabatan kepercayaan yang wajib dipertanggungjawabkan secara hukum maupun secara etika profesi. Suatu akta yang dibuat oleh notaris adalah akta yang bersifat autentik sehingga didalam membuat akta notaris harus lebih berhati - hati serta sesuai dengan peraturan. Terhadap akta yang dibuat oleh pihak notaris maka pihak notaris harus bertanggung 
jawap saat akta yang dibuatnya terdapat suatu kesalahan maupun pelanggaran yang dilakukan oleh pihak notaris. ${ }^{13}$

Pihak notaris merupakan pejabat yang memang sepantasnya untuk dapat memberikan pelayanan yang sebaik - baiknya terhadap masyarakat. Tetapi didalam suatu hal tertentu notaris juga dapat menolak didalam memberikan pelayanan terkait dengan suatu hal tertentu. Peran notaris didalam menuntukan apakah suatu hal dapat dituangkan atau tidak kedalam suatu akta ditentukan melalui pertimbangan yang dilakukan oleh pihak notaris dengan melihat serta meneliti dokumen yang diberikan kepadanya maupun alat bukti yang diberikan serta dengan mendengarkan keterangan yang disampaikan oleh para pihak. Pertimbangan yang dilakukan oleh pihak notaris dengan memperhatikan aspek hukum maupun masalah yang mungkin bisa terjadi dikemudian hari. ${ }^{14}$

Terkait dengan permasalahan pihak klien yang datang menghadap notaris untuk ingin dibuatkan akta jaminan fidusia yang hanya membawa kuitansi sebagai bukti kepemilikan kendaraan bermotor maka pihak notaris akan meneliti bukti kuitansi sebagai bukti tanda kepemilikan kendaraan bermotor dapat menolak untuk memberikan pelayan yaitu membuatkan akta jaminan fidusia. Selain bukti kuitansi hanya merupakan bukti surat dibawah tangan yang tidak memiliki pembuktian yang sempurna pihak notaris juga memperhatikan masalah hukum yang mungkin bisa terjadi dikemudian hari yang dapat merugikan pihak notaris. Hanya pihak klien yang namanya tertera didalam BPBK yang dapat membebankan kendaraan bermotornya dengan jaminan fidusia. BPBK merupakan tanda bukti surat autentik yang memiliki kekuatan pembuktian kepemilikan kendaraan bermotor yang sempurna.

Sanksi bagi pihak notaris jika terjadinya masalah pada akta fidusia yang dibuatnya terkait dengan kuitansi yang digunakan sebagai alat bukti adalah akta yang dibuatnya menjadi batal demi hukum. Hal tersebut disebabkan karena hanya pihak pemilik yaitu pihak yang namanya tertera didalam BPKB yang dapat menjaminkan kendaraan bermotor. Sehingga apabila bukan pihak yang namanya tertera didalam BPKB yang menjaminkan kendaraan bermotor yang didalam akta jaminan fidusia adanya perbedaan nama yang tertera antara pihak yang membebankan jaminan fidusia dengan yang tertera didalam BPKB maka akta fidusia aktanya menjadi batal demi hukum. Terhadap perjanjian dalam bentuk perjanjian kredit yang dibuat dengan jaminan barang bergerak yang dibebankan dengan jaminan fidusia maka akta jaminan fidusia yang dibuat oleh pihak notaris yang bersangkutan tersebut akan menjadi akta dibawah tangan. Suatu akta autentik yang hanya memiliki kekuatan pembuktian dibawah tangan maupun menjadi akta yang batal demi hukum maka dapat menjadi alasan bagi para pihak yang dirugikan untuk meminta ganti rugi terhadap pihak notaris maka perlunya kehati hatian serta ketelitian dari pihak notaris didalam membuat suatu akta autentik.

${ }^{13}$ Diana, P. V. P., Mertha, I. K., \& Artha, I. G. (2015). PERTANGGUNG JAWABAN NOTARIS DALAM PEMBUATAN AKTA BERDASARKAN PEMALSUAN SURAT OLEH PARA PIHAK. Acta Comitas, 161-172.h. 7

14 Sundah, P. (2014). TINJAUAN YURIDIS TERHADAP TIDAK DILAKSANAKANNYA KEWAJIBAN JABATAN NOTARIS MENURUT UNDANG-UNDANG NO. 2 TAHUN 2014. LEX ET SOCIETATIS, 2(4). h.3 
Upaya didalam mencegah terdegradasinya suatu akta autentik menjadi akta dibawah tangan atau menjadi akta yang batal demi hukum maka didalam menjalankan tugasnya notaris harus menaati ketentuan yang ada didalam UUJN maupun peraturan substantif lainnya. Kedudukan suatu akta yang dibuat notaris merupakan suatu alat bukti yang sempurna selama sesuai dengan prosedur UUJN dan apabila akta yang dibuat tidak sesuai dengan UUJN maka kekuatan pembuktian akta tersebut hanya sebatas akta dibawah tangan sesuai dengan ketentuan pasal 41 UUJN. Suatu akta notaris yang dibuat menjadi batal demi hukum dikarenakan tidak memenuhinya syarat subjektif maupun syarat objektifnya. ${ }^{15}$

\section{Kesimpulan}

Berdasarkan hasil penelitian tersebut, Keabsahan Kuitansi sebagai suatu alat bukti hanya sebatas alat bukti surat dibawah tangan yang memiliki pembuktian formil serta kekuatan pembuktian yang tidak sempurna. Terkait dalam hal pembuktian kepemilikan kendaraan bermotor dengan bukti kuitansi bukan merupakan suatu alat bukti yang kuat karena bukti autentik dari kepemilikan suatu kendaraan bermotor yaitu dengan bukti kepemilikan BPKB karena BPKB merupakan bukti surat yang dibuat oleh pejabat yang berwenang sehingga memiliki kekuatan pembuktian yang sempurna. Pihak klien yang datang menghadap notaris dengan membawa bukti kuitansi sebagai tanda bukti kendaraan bermotor maka akan ditolak oleh pihak notaris dikarenakan hanya pihak pemilik yang namanya tertera didalam BPKB yang dapat menjaminkan kendaraan bermotor dengan jaminan fidusia. Selain itu didalam hal penandatangan suatu akta jaminan fidusia maka nama pihak pemberi jaminan fidusia harus sama dengan nama pihak yang tertera didalam BPKB sehingga hanya pihak yang namanya tertera didalam BPKB yang dapat menandatangani akta jaminan fidusia tersebut. Sanksi bagi pihak notaris jika terjadi permasalahan pada akta fidusia yang dibuatnya terkait kuitansi sebagai alat bukti maka akta yang dibuat menjadi batal demi hukum karena hanya pihak pemilik yang namanya tertera didalam BPKB yang dapat menjaminkan kendaraan bermotornya dengan jaminan fidusia. Dalam hal perjanjian kredit dengan pembebanan jaminan fidusia maka sanksi bagi pihak notaris akta jaminan fidusia yang terdegradasi menjadi akta dibawah tangan.

\section{Daftar Pustaka}

Buku

Soekanto Soerjono. (2012). Pengantar penelitian Hukum. Jakarta:UI Press

Suryohadibroto Imam Prayoga, Djoko Prakoso. (2010). Surat Berharga Alat Pembayaran dalam Masyarakat Moderen. Jakarta: PT Bina Aksara

Tumbuan, Fred B.G. (2009). Mencermati Pokok-Pokok RUU Jaminan Fidusia. Newsletter Nomor 38 Tahun X. Jakarta : Yayasan pusat pengkaijian hukum

Usman Rachmadi. (2009). Hukum Jaminan Keperdataan. Jakarta: Sinar Grafika

\section{Jurnal}

Diana, P. V. P., Mertha, I. K., \& Artha, I. G. (2015). PERTANGGUNG JAWABAN NOTARIS DALAM PEMBUATAN AKTA BERDASARKAN PEMALSUAN SURAT OLEH PARA PIHAK. Acta Comitas, 161-172

\footnotetext{
${ }^{15}$ Mowoka, V. P. (2014). Pelaksanaan Tanggung Jawab Notaris terhadap Akta yang Dibuatnya. LEX ET SOCIETATIS, 2(4). h.5
} 
Hayatdian, H. D. (2013). Kajian Hukum Surat Kuasa Dibawah Tangan Sebagai Dasar Pembuatan Akta Jaminan Fidusia. Jurnal Hukum Unsrat, 1(1), 120-135

Mowoka, V. P. (2014). Pelaksanaan Tanggung Jawab Notaris terhadap Akta yang Dibuatnya. LEX ET SOCIETATIS, 2(4)

Palit, R. C. (2015). Kekuatan Akta di Bawah Tangan Sebagai Alat Bukti di Pengadilan. Lex Privatum, 3(2).

Sundah, P. (2014). TINJAUAN YURIDIS TERHADAP TIDAK DILAKSANAKANNYA KEWAJIBAN JABATAN NOTARIS MENURUT UNDANG-UNDANG NO. 2 TAHUN 2014. LEX ET SOCIETATIS, 2(4).

Winarno, J. (2013). Perlindungan Hukum bagi Kreditur pada Perjanjian Jaminan Fidusia. Jurnal Independent, 1(1)

\section{$\underline{\text { Tesis/Disertasi }}$}

Nenden Dewi Anggraeni. (2012). Analisis Perlindungan Hukum Pemegang Jaminan Fidusia Studi Kasus Putusan Mahkamah Agung Nomor 1602/Pdt/2007 (Thesis, Program Magister kenotariatan Universitas Indonesia

\section{Peraturan Perundang-Undangan}

Kitab Undang-Undang Hukum Perdata (Burgerlijk Wetboek)

Undang - Undang Republik Indonesa Nomor 42 Tahun 1999 tentang Jaminan Fidusia, Lembaran Negara Republik Indonesia Nomor 168 tahun 1999, Tambahan Lembaran Negara Republik Indonesia Nomor 3889

Undang-Undang Republik Indonesia Nomor 2 Tahun 2014 tentang Perubahan Atas Undang-Undang Nomor 30 Tahun 2004 Tentang Jabatan Notaris, Lembaran Negara Republik Indonesia Tahun 2014 Nomor 293, Tambahan Lembaran Negara Republik Indonesia Nomor 5602. 